\title{
PENGARUH PENDIDIKAN KESEHATAN SADARI DENGAN MEDIA SLIDE DAN BENDA TIRUAN TERHADAP PERUBAHAN PENGETAHUAN WUS
}

\author{
INFLUENCE OF BSE HEALTH EDUCATION WITH SLIDE AND ARTIFICIAL \\ OBJECT TO CHANGE WCA KNOWLEDGE
}

\author{
Utut Andita \\ Departemen Promosi Kesehatan dan Ilmu Perilaku, \\ Fakultas Kesehatan Masyarakat, Universitas Airlangga, Surabaya \\ Email: andita.utut@yahoo.com
}

\begin{abstract}
In 2012 there were 1.7 million women suffering from breast cancer, the disease is the most common cause of death in women (IARC, 2013). Deaths from breast cancer due to a delayed in diagnosis. Breast Self Examination (BSE) is one of the method for early detection of breast cancer, by doing this way routinely proven to lower the mortality rate of breast cancer about 25-30\%. However, actually there are many Women of Childbearing Age (WCA) who don't know about BSE. The aim of this study was to analyses the influence of SADARI health education on WCA knowledge. The study design was used One Group Pre Test Post Test with Pre Experimental Design. Population of this study was $W C A$ at $P K K$ of RW 03 in Karang Widoro Village, Malang, numbering 113 people and samples used by 31 people with incidental sampling technique. Instrument was used by using questionnaires. The results of analysis using the Paired t-test is $\rho=0.00<\alpha=0.05$. This means that there are influence BSE health education with slide and artificial object media to change WCA knowledge. The conclusion of this study is increase very significantly in the respondents' knowledge after health education BSE with merge slide and artificial object media. Suggestions for provider to conduct health education by using appropriate media merger.
\end{abstract}

Keywords: BSE, Knowledge, WCA

\begin{abstract}
Abstrak: Pada tahun 2012 terdapat 1,7 juta wanita menderita kanker payudara, penyakit ini merupakan penyebab kematian paling umum pada wanita (IARC, 2013). Kematian akibat kanker payudara disebabkan keterlambatan dalam diagnosis. Pemeriksaan payudara sendiri (SADARI) adalah salah satu cara untuk deteksi dini kanker payudara, dengan melakukan metode ini secara rutin terbukti dapat menurunkan angka kematian penderita kanker payudara sebesar 25-30\%. Namun, pada kenyataannya masih banyak Wanita Usia Subur (WUS) yang belum mengetahui tentang SADARI. Tujuan dari penelitian ini adalah untuk menganalisis pengaruh pendidikan kesehatan SADARI terhadap perubahan pengetahuan WUS. Desain penelitian ini menggunakan Pre Experimental Design dengan pendekatan One Group Pre Test Post Test Design. Populasi dalam penelitian ini adalah WUS di PKK RW 03 Desa Karang Widoro, Malang sejumlah 113 orang dan sampelnya sejumlah 31 orang yang diambil dengan teknik incidental sampling. Instrument yang digunakan adalah kuesioner. Hasil analisis dengan menggunakan Paired t-test adalah $\rho=0.00<\alpha=0.05$. Hal ini berarti terdapat pengaruh pendidikan kesehatan SADARI dengan media slide dan benda tiruan terhadap perubahan pengetahuan WUS. Kesimpulan dari penelitian ini adalah terdapat peningkatan pengetahuan secara sangat signifikan terhadap responden setelah dilakukan pendidikan kesehatan SADARI dengan menggunakan penggabungan media slide dan benda tiruan. Saran untuk pemberi pendidikan kesehatan adalah untuk melakukan pendidikan kesehatan dengan menggunakan penggabungan media secara tepat.
\end{abstract}

Kata kunci: SADARI, Pengetahuan, WUS

\section{PENDAHULUAN}

WUS atau yang disebut eligible women merupakan wanita yang organ reproduksinya sudah berfungsi dengan baik, WUS merupakan wanita yang berusia $20-45$ tahun
(Mubarak, 2011). Pada usia tersebut wanita memiliki kerentanan untuk terkena penyakit kanker payudara atau carcinoma mammae. Menurut Lee (2008) bahwa wanita memiliki risiko tertinggi terkena kanker payudara pada usia pertengahan 30 tahun hingga 
pertengahan 40 tahun. Sehingga, pada usia tersebut wanita harus lebih waspada terhadap tanda dan gejala kanker payudara.

Kanker payudara merupakan pembelahan sel secara tidak terkendali yang berasal dari kelenjar, saluran kelenjar dan jaringan penunjang mamae tidak termasuk kulit payudara (Romauli, 2009). Selain itu menurut Nisman (2011) kanker payudara merupakan kanker yang terjadi pada kelenjar mamae karena terjadi keganasan sel atau pertumbuhan sel yang tidak terkendali dari sel kelenjar dan salurannya, secara normal sel akan tumbuh sesuai dengan kebutuhan tubuh, tetapi lain halnya dengan kanker payudara, sel yang rusak tidak langsung mati, melainkan membangun sel baru yang jumlahnya melebihi kebutuhan tubuh.

Penyebab pasti kanker payudara masih belum diketahui. Tetapi terdapat beberapa faktor risiko terjadinya penyakit tersebut. Depkes (2009) menyatakan bahwa faktor risiko kanker payudara, meliputi: adanya riwayat kanker payudara pada anggota keluarga tingkat pertama (ibu atau kakak atau adik); pernah menjadi penderita kanker payudara; wanita yang tidak mempunyai anak atau biasa disebut nulipara; hamil pertama pada usia $>30$ tahun; mulai haid pertama atau menarche pada usia dini atau mengalami menopause terlambat; gangguan haid; konsumsi lemak yang berlebihan; merokok tembakau. Selain itu Andrew (2009) menyatakan bahwa faktor risiko kanker payudara, yaitu: tidak menyusui (wanita yang tidak menyusui memiliki risiko lebih tinggi terkena kanker payudara); menggunakan kontrasepsi oral; melakukan terapi sulih hormon; pemajanan terhadap radiasi; variasi geografi.

Tanda dan gejala yang khas tidak terlihat pada tahap awal, namun terlihat pada tahap lanjut. Romauli (2009) menyatakan bahwa tanda gejala tersebut meliputi: terdapat benjolan pada payudara; borok atau luka yang tidak sembuh pada payudara; pada puting susu keluar cairan yang tidak normal, seperti nanah, darah, cairan encer atau keluar air susu pada wanita yang tidak hamil ataupun menyusui; perubahan bentuk dan ukuran payudara; kulit puting susu maupun areola berkerut; nyeri pada payudara. Selain itu, menurut Depkes (2009) menyatakan bahwa tanda lain yang harus diwaspadai adalah warna kulit payudara yang lebih kemerahan dan lebih mengkilat; apabila diraba terdapat bagian payudara yang terasa lebih hangat dibandingkan dengan daerah sekitarnya.

Berdasarkan laporan dari The International Agency for Research on Cancer (IARC) (2013) menunjukkan bahwa pada tahun 2012, 1,7 juta wanita didiagnosis menderita kanker payudara, sejak tahun 2008 diperkirakan insiden kanker payudara bertambah lebih dari $20 \%$, sementara kematian bertambah $14 \%$, kanker payudara merupakan penyebab kematian paling umum pada wanita (522.000 kematian pada tahun 2012) dan kanker yang paling sering didiagnosis pada wanita di 140 dari 184 negara di seluruh dunia. Di Jawa Timur, angka prevalensi kanker payudara berdasarkan Riskesdas (2013) dalam Profil Kesehatan Indonesia (2013) sebanyak 1,6 $\%$ dari rata-rata jumlah penderita kanker payudara se-Indonesia yaitu $1,4 \%$.

Purwanto (2010) menyatakan bahwa kematian akibat kanker payudara cukup tinggi dikarenakan pasien datang dengan kondisi terlambat, berdasarkan data dari RS Dharmais bahwa jumlah pasien kanker payudara yang datang dalam stadium dini (stadium I dan II) adalah 13,42\%, stadium III adalah $17 \%$ dan sebanyak $29,98 \%$ datang pada stadium lanjut (stadium IV), pasien paling banyak datang dengan kekambuhan yaitu sebesar 39,66\%. Keterlambatan diagnostik dikarenakan ketidaktahuan pasien (patient delay), ketidaktahuan dokter (doctor delay) atau keterlambatan rumah sakit (hospital delay).

Upaya penurunan angka kesakitan dan kematian akibat kanker payudara diperlukan dukungan dari berbagai pihak. Hal ini bukan hanya menjadi tanggung jawab tenaga medis, namun peran aktif dari setiap wanita sangat diperlukan. Setiap wanita harus mengetahui apabila terdapat perubahan pada payudaranya menjadi tidak normal. Sedangkan sebagai tenaga medis, harus memberikan penanganan yang tepat. Manuaba (2010) menyatakan bahwa penanganan tumor dilakukan dengan memberikan KIE dan motivasi tentang tumor ataupun keganasan payudara, penemuan 
sedini mungkin, melakukan rujukan pasien sehingga mendapat penanganan lebih lanjut, dan melakukan pemeriksaan lanjutan setelah pengobatan dari rumah sakit.

SADARI merupakan pemeriksaan pada payudara sendiri untuk menemukan benjolan yang abnormal (Mulyani, 2013). Selain itu Romauli (2009) menyatakan bahwa SADARI adalah usaha atau cara pemeriksaan pada payudara secara rutin dan sistematik yang digunakan sebagai upaya untuk screening kanker payudara. SADARI dilakukan dengan tujuan untuk mendeteksi sedini mungkin adanya kanker payudara, sehingga bisa dilakukan pengobatan sedini mungkin dan untuk menurunkan angka kematian akibat kanker payudara. Cara ini sangat efektif dan efisien karena dengan melakukan SADARI secara rutin dapat menekan angka kematian sebesar $25-30 \%$.

Keuntungan yang didapat dengan melakukan SADARI adalah dapat meningkatkan harapan hidup penderita kanker payudara, karena dapat terdeteksi secara dini serta metode ini dapat dilakukan dengan mudah, murah, dan sederhana. Pada pemeriksaan payudara sendiri ini hampir $85 \%$ benjolan abnormal ditemukan oleh penderita sendiri melalui pemeriksaan dengan langkah yang benar (Nisman, 2011). SADARI dapat dilakukan setiap satu minggu setelah haid, apabila telah berhenti haid atau menopause maka SADARI dapat dilakukan setiap satu bulan sekali pada waktu yang sama (Nisman, 2011). SADARI harus dilakukan oleh setiap wanita dewasa, utamanya pada wanita usia subur (WUS).

Perilaku deteksi dini dengan SADARI dapat dilakukan dengan baik apabila pengetahuan yang dimiliki baik. Pada penelitian Ekanita (2013) didapatkan bahwa responden yang memiliki pengetahuan baik tentang SADARI lebih banyak yang melakukan SADARI secara rutin, dan tidak ada yang tidak pernah melakukan SADARI. Sedangkan pada responden yang memiliki pengetahuan kurang sebagian besar tidak pernah melakukan SADARI. Pamungkas (2015) menyatakan bahwa seseorang yang memiliki pengetahuan baik cenderung akan memiliki perilaku SADARI yang baik pula.
Perilaku SADARI dapat dilakukan dengan baik dan dapat bertahan lama apabila seseorang tersebut memiliki pengetahuan mengenai SADARI yang baik pula. Rogers (1974) dalam Notoatmojo (2012) menyatakan bahwa perilaku akan bertahan lama apabila seseorang tersebut memiliki kesadaran dan pengetahuan yang baik dan sebaliknya, apabila seseorang tersebut tidak memiliki kesadaran dan pengetahuan maka perilaku tersebut akan bertahan sementara.

Pada kenyataan yang ada di masyarakat utamanya di Desa Karang Widoro Kecamatan Dau Malang, masih banyak wanita yang belum mengetahui mengenai SADARI. Studi pendahuluan yang telah dilakukan di Desa Karang Widoro, Kecamatan Dau Malang didapatkan hanya 2 dari 10 orang WUS yang mengetahui tentang SADARI. Berdasarkan hal tersebut, maka perlu dilakukan upaya peningkatan pengetahuan WUS tentang SADARI dengan cara memberikan pendidikan kesehatan SADARI terhadap WUS. Tujuan dari penelitian ini adalah untuk menganalisis pengaruh pendidikan kesehatan SADARI terhadap pengetahuan WUS di Desa Karang Widoro, Kecamatan Dau, Malang.

\section{METODE}

Desain penelitian yang digunakan pada penelitian ini adalah "Pre Experimental Design" atau sering disebut "Quasi Experiment" dengan menggunakan rancangan "One Group Pre Test Post Test Design". Berikut rancangan penelitian yang akan dilakukan:

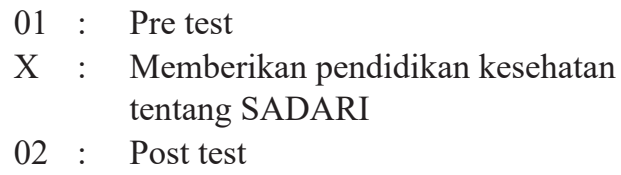

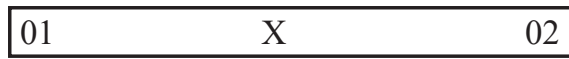

Penelitian ini dilakukan di wilayah RW 03 Desa Karang Widoro, Kecamatan Dau, Malang selama 7 bulan, yaitu mulai bulan Desember 2013 hingga Juli 2014. Populasi dalam penelitian ini adalah WUS di PKK RW 03 Desa Karang Widoro, Kecamatan 
Dau, Malang sejumlah 113 orang. Teknik pengambilan sampel yang digunakan adalah purposive sampling dan didapatkan sampel sebanyak 31 orang.

Kriteria inklusi pada penelitian ini meliputi: wanita yang berusia $20-45$ tahun; bersedia untuk menjadi responden; responden mengikuti pre test dan pos test; hadir pada saat dilakukan pendidikan kesehatan.

Variabel independent atau variabel bebas pada penelitian ini adalah pendidikan kesehatan tentang SADARI sedangkan variabel dependent atau variabel terikatnya adalah pengetahuan WUS tentang SADARI. Pengetahun WUS akan dilakukan scoring dengan rumus:

$$
\mathrm{N}=\frac{S p}{S m} \times 100 \%
$$

Keterangan :

$\begin{array}{ll}\mathrm{N} & =\text { nilai yang didapat } \\ \mathrm{Sp} & =\text { skor yang didapat } \\ \mathrm{Sm} & =\text { skor maksimal }\end{array}$

Interpretasi data :

Baik : $76 \%-100 \%$

Cukup : $56 \%-75 \%$

Kurang : $<56 \%$

Sumber data didapatkan dengan 2 cara, yaitu secara primer dan sekunder. Secara primer, yaitu dengan memberikan kuesioner sebelum dilakukan pendidikan kesehatan SADARI dan setelah dilakukan pendidikan kesehatan SADARI. Serta dilakukan secara sekunder yaitu dengan melihat data WUS yang ada di PKK RW 03 yang terdapat di Kelurahan Karang Widoro.

Instrument yang digunakan dalam penelitian ini adalah berupa kuesioner. Bentuk pertanyaan yang digunakan adalah bentuk pertanyaan tertutup (closed ended) dan jenis pertanyaan yang digunakan adalah multiple choice, sehingga responden hanya boleh memilih satu di antara beberapa jawaban yang paling dianggap benar oleh responden.

Teknik pengumpulan data secara primer dilakukan dengan beberapa langkah berikut: (1) memberikan penjelasan tentang maksud dan tujuan kepada responden mengenai penelitian yang akan dilakukan; (2) memberikan inform consent kepada responden untuk diisi dan ditandatangani sebagai tanda kesediaan untuk menjadi responden; (3) membagikan kuesioner kepada setiap responden untuk diisi; (4) melakukan pre test dengan menjelaskan tentang pertanyaan yang ada di dalam kuesioner dan cara mengisinya serta memberikan kesempatan kepada responden untuk bertanya jika ada hal yang kurang dimengerti; (5) memberikan pendidikan kesehatan tentang SADARI; (6) melakukan post test dengan membagikan kuesioner untuk diisi responden, setelah selesai dikumpulkan kembali.

Media yang digunakan untuk pendidikan kesehatan tentang SADARI adalah menggunakan slide show, yang berisi tentang pengertian kanker payudara (carcinoma mammae), penyebab kanker payudara, pengertian SADARI (pemeriksaan payudara sendiri), tujuan SADARI, manfaat melakukan SADARI secara rutin, waktu yang tepat untuk pemeriksaan payudara sendiri, orang yang harus melakukan pemeriksaan payudara sendiri, tahapan melakukan SADARI, keadaan payudara yang bermasalah pada saat SADARI, dan langkah yang harus dilakukan ketika menemukan masalah pada payudara pada saat SADARI; selain itu media yang digunakan adalah benda tiruan berupa phantom payudara.

Analisis data tentang pengaruh pendidikan kesehatan SADARI terhadap perubahan pengetahuan WUS dilakukan dengan menggunakan uji statistik Paired t-test.

\section{HASIL PENELITIAN}

Desa Karang Widoro merupakan salah satu wilayah di daerah Kabupaten Malang tepatnya di Kecamatan Dau. Di desa Karang Widoro ini terbagi menjadi 3 wilayah RW, dan salah satu tempat yang dilakukan penelitian adalah di PKK RW 03. Masyarakat setempat memiliki rasa gotong royong yang tinggi. Hal ini dapat dilihat dari kebiasaan masyarakat setempat untuk membantu tetangga yang sedang memiliki hajatan secara antusias dan sukarela. 
Ibu-ibu di wilayah setempat sebagian besar adalah ibu rumah tangga. Namun ada beberapa yang bekerja di bidang swasta, misalnya PRT (pembantu rumah tangga), pedagang, dan buruh pabrik selain itu ada beberapa yang bekerja sebagai petani. Di wilayah ini kegiatan rutin yang biasa dilakukan adalah perkumpulan PKK yakni setiap satu minggu sekali.

Karakteristik responden berdasarkan umur, jenis pekerjaan dan tingkat pendidikan.

Tabel 1. Distribusi Frekuensi Responden Berdasarkan Umur, Jenis Pekerjaan dan Tingkat Pendidikan di PKK RW 03, Desa Karang Widoro, Dau, Malang

\begin{tabular}{llrr}
\hline Karakteristik Responden & $(\boldsymbol{f})$ & $\mathbf{( \% )}$ \\
\hline \multirow{4}{*}{ Umur } & $20-29$ & 6 & 19 \\
& $30-39$ & 16 & 52 \\
& $40-45$ & 9 & 29 \\
\cline { 2 - 4 } Jenis & Total & $\mathbf{3 1}$ & $\mathbf{1 0 0}$ \\
Pekerjaan & Swasta & 9 & 29 \\
& Petani & 2 & 6 \\
& IRT & 20 & 65 \\
\cline { 2 - 4 } Pendidikan & Total & $\mathbf{3 1}$ & $\mathbf{1 0 0}$ \\
& SD & 16 & 52 \\
& SMP & 11 & 35 \\
& SMA & 4 & 13 \\
\cline { 2 - 4 } & Total & $\mathbf{3 1}$ & $\mathbf{1 0 0}$ \\
\hline
\end{tabular}

Berdasarkan Tabel 1 sebagian besar responden memiliki pendidikan yang rendah. pendidikan yang rendah ini dapat mengindikasikan pengetahuan responden tentang SADARI menjadi kurang. Rendahnya pendidikan responden dikarenakan wilayah rumah responden yang berada di pedesaan, dimana biasanya bagi orang desa jenjang pendidikan yang tinggi masih belum diutamakan untuk wanita.

Selain itu faktor biaya juga dapat menjadi kendala untuk mendapatkan pendidikan yang lebih tinggi.

Hasil tabulasi responden sebelum diberikan pendidikan kesehatan (pre-test) dan setelah diberikan pendidikan kesehatan (post-test) tentang SADARI di PKK RW 03 Desa Karang Widoro, Kecamatan Dau, Malang dapat dilihat pada Tabel 2.
Tabel 2. Hasil Tabulasi Pengetahuan Responden Sebelum (Pre Test) dan Setelah (Post Test) Diberikan Pendidikan Tentang SADARI

\begin{tabular}{llrc}
\hline \multicolumn{2}{c}{ Tingkat Pengetahuan } & $(\boldsymbol{f})$ & $\mathbf{( \% )}$ \\
\hline \multirow{3}{*}{ Pre test } & Baik & 1 & 03 \\
& Cukup & 12 & 39 \\
& Kurang & 18 & 58 \\
\hline \multirow{3}{*}{ Post test } & Baik & 23 & 74 \\
& Cukup & 8 & 26 \\
& Kurang & 0 & 00 \\
\hline
\end{tabular}

Berdasarkan tabel 2 dapat diketahui dikarenakan tingkat pendidikan responden yang rendah sehingga pengetahuan responden tentang SADARI sebagian besar juga kurang, hal ini dapat terjadi karena upaya responden secara aktif untuk mengakses infomasi kesehatan masih kurang. Selain itu, setelah dilakukan pendidikan kesehatan dapat diketahui terdapat perubahan pengetahuan secara positif, dimana terdapat peningkatan pengetahuan pada semua responden.

Berdasarkan Tabel 2 didapatkan perbedaan yang begitu terlihat tentang pengetahuan WUS sebelum dan setelah diberikan pendidikan kesehatan SADARI. Yang awalnya pengetahuan responden sebagian besar kurang, setelah diberikan pendidikan kesehatan SADARI pengetahuan WUS menjadi sebagian besar baik dan sudah tidak ada lagi yang berpengetahuan kurang.

Meskipun secara keseluruhan dari responden mengalami peningkatan pengetahuan. Namun, peningkatan pengetahuan yang ada sangat bervariasi. Peningkatan pengetahuan yang bervariasi ini di pengaruhi oleh berbagai faktor, misalnya ketertarikan responden untuk mendapatkan informasi tentang SADARI, daya tangkap responden terhadap suatu informasi, dan keberhasilan penceramah untuk mentransferkan informasi ke responden. Hal ini dapat dilihat pada tabel 3 .

Pada tabel 3 didapatkan peningkatan jawaban benar pada seluruh item pertanyaan. Peningkatan jawaban benar tersebut sangat bervariasi. Hal ini dapat terjadi karena pada beberapa informasi disampaikan lebih sering 
Tabel 3. Analisis Jumlah Responden dengan Jawaban Benar per Butir Soal

\begin{tabular}{lrrrr}
\hline \multirow{2}{*}{$\begin{array}{c}\text { Kelompok } \\
\text { Soal }\end{array}$} & \multicolumn{3}{c}{ Jumlah Responden dengan } \\
& \multicolumn{2}{c}{ Pre test } & \multicolumn{2}{c}{ Post test } \\
\cline { 2 - 5 } Pengertian & 18 & 58,06 & 20 & 64,52 \\
& 6 & 45,16 & 25 & 80,65 \\
\hline Tujuan dan & 19 & 61,29 & 29 & 93,55 \\
manfaat & 23 & 74,19 & 30 & 96,77 \\
\hline \multirow{2}{*}{ Syarat } & 25 & 80,65 & 30 & 96,77 \\
& 9 & 29,03 & 18 & 58,06 \\
\hline \multirow{2}{*}{ Waktu } & 13 & 41,94 & 16 & 51,61 \\
\hline \multirow{2}{*}{ Langkah } & 9 & 29,03 & 29 & 93,55 \\
& 15 & 48,39 & 28 & 90,32 \\
\hline Masalah yang & 15 & 48,39 & 29 & 93,55 \\
ditemukan & 11 & 35,48 & 25 & 80,65 \\
\hline \multirow{2}{*}{ Tindakan } & 6 & 19,35 & 22 & 70,92 \\
\hline Rata-rata & 24 & 74,19 & 30 & 96,77 \\
\hline
\end{tabular}

baik pada media slide maupun benda tiruan. Selain itu terdapat beberapa informasi yang dilakukan secara demonstrasi sehingga informasi yang diterima lebih banyak. Misalnya pada langkah SADARI, selain ditampilkan di slide, responden juga diminta untuk mengikuti gerakan SADARI yang telah didemonstrasikan dengan menggunakan benda tiruan.

Selain itu dari tabel 3 didapatkan perbedaan secara positif rata-rata pengetahuan setelah dan sebelum dilakukan pendidikan kesehatan SADARI, yaitu terdapat peningkatan sebesar 31,18.

Hasil analisis data mengenai pengaruh pendidikan SADARI terhadap peningkatan pengetahuan WUS yang telah dilakukan dengan uji statistik Paired $t$-test didapatkan $\rho=0,000$. Hal ini berarti terdapat pengaruh pendidikan kesehatan SADARI dengan media slide dan benda tiruan terhadap perubahan pengetahuan WUS secara sangat signifikan di PKK RW 03, Desa Karang Widoro, Kecamatan Dau, Malang.

Pada penelitian ini pendidikan kesehatan SADARI dilakukan dengan menggabungkan dua metode, yaitu metode ceramah dan demonstrasi. Pada metode ceramah, media yang digunakan adalah dengan menggunakan slide. Langkah yang dilakukan pada metode ini adalah, penceramah menampilkan slide yang ada dan menjelaskan tentang pengertian kanker payudara (carcinoma mammae), penyebab kanker payudara, pengertian SADARI, tujuan SADARI, manfaat melakukan SADARI secara rutin, waktu yang tepat untuk SADARI, orang yang harus melakukan SADARI, tahapan melakukan SADARI, keadaan payudara yang bermasalah pada saat SADARI, dan langkah yang harus dilakukan ketika menemukan masalah pada payudara pada saat SADARI. Metode ini dilakukan secara dua arah, dimana responden dapat memberikan pendapat mengenai SADARI selain itu setelah dilakukan pendidikan kesehatan SADARI responden dapat menanyakan hal yang kurang jelas tentang penjelasan yang ada.

Selanjutnya pada metode demonstrasi dengan benda tiruan, yaitu phantom payudara. Langkah yang dilakukan adalah, di depan terdapat instruktur yang memperagakan langkah SADARI dengan menggunakan benda tiruan. Pada saat dilakukan demonstrasi dengan benda tiruan, responden diminta untuk menirukan langkah yang ada dan dilakukan pendampingan dalam memperagakannya.

Hasil dari pendidikan kesehatan ini didapatkan sebagian besar responden antusias dengan pendidikan kesehatan SADARI ini. Hal ini dapat ditunjukkan dengan beberapa responden yang mengajukan pertanyaan tentang SADARI. Selanjutnya responden mengikut seluruh langkah yang dilakukan pada saat demonstrasi dengan baik.

\section{PEMBAHASAN}

Pengetahuan WUS sebelum diberikan pendidikan kesehatan SADARI didapatkan sebagian besar memiliki pengetahuan kurang. Pengetahuan atau yang disebut (knowledge) menurut Notoatmodjo (2011) merupakan hasil tahu (know) dari manusia yang sekedar menjawab pertanyaan apa 
(what). Selain itu menurut Mubarak (2011) pengetahuan adalah hasil mengingat sesuatu hal, termasuk mengingat kembali hal yang pernah dilakukan baik yang disengaja atau tidak disengaja dan hal ini terjadi setelah orang tersebut melakukan kontak atau pengamatan terhadap suatu objek tertentu. Sehingga pengetahuan adalah hasil tahu (know) yang dimiliki seseorang akibat melakukan suatu kontak atau pengamatan pada suatu objek.

Pengetahuan setiap orang terhadap suatu objek pasti berbeda. Hal ini dapat terjadi karena beberapa faktor. Faktor yang mempengaruhinya terbagi menjadi dua, yaitu faktor internal dan eksternal, pada faktor internal misalnya pendidikan dan pekerjaan sedangkan untuk faktor eksternal misalnya lingkungan (Nisman, 2011).

Andita (2014) menyatakan bahwa tingkat pendidikan pada setiap individu sangat berpengaruh terhadap kehidupannya, apabila seseorang semakin tinggi pendidikannya, maka mereka memiliki kesempatan yang lebih besar untuk mendapatkan informasi terbaru. Hal ini terjadi karena semakin tinggi pendidikan seseorang maka semakin tinggi pula kemampuan seseorang untuk mendapatkan informasi. Sehingga secara tidak langsung hal ini akan mempengaruhi banyaknya pengetahuan yang didapatkan oleh setiap individu. Hal ini sesuai dengan pendapat Wawan (2011) yang menyatakan bahwa pendidikan seseorang dapat menentukan individu tersebut dalam melakukan suatu hal dalam kehidupannya, yang dapat digunakan untuk mencapai kesejahteraan, pendidikan diperlukan untuk mendapatkan informasi misalnya hal yang menunjang kesehatan sehingga dapat meningkatkan kualitas hidup. Selain itu menurut YB Mantra yang dikutip Notoatmodjo (2012) menyatakan bahwa pendidikan dapat mempengaruhi perilaku seseorang akan pola hidupnya, terutama dalam memotivasi untuk sikap berperan serta dalam pembangunan.

Hal ini juga sesuai dengan penelitian dalam Widiawaty (2011) yang menyatakan bahwa terdapat hubungan yang signifikan antara tingkat pendidikan dengan tingkat pengetahuan responden, terlihat bahwa responden yang memiliki pendidikan menengah dan tinggi sebagian besar memiliki pengetahuan baik dan cukup, serta tidak ada yang memiliki pengetahuan kurang. Sedangkan untuk tingkat pendidikan dasar masih ada yang memiliki pengetahuan kurang.

Selanjutnya faktor pekerjaan, berdasarkan hasil identifikasi didapatkan sebagian besar responden adalah ibu rumah tangga dan terbanyak kedua adalah memiliki pekerjaan swasta. Pekerjaan seseorang pasti akan mempengaruhi kehidupan sehari harinya. Hal ini terjadi karena responden yang bekerja, misalnya pada responden yang menjadi buruh pabrik, mereka seharian melakukan pekerjaannya di tempat kerjanya, kemudian melakukan berbagai aktivitas rumah tangga. Sehingga responden sudah merasa letih, dan waktu untuk mencari informasi secara aktif terutama mengenai pencegahan kanker payudara (ca mammae) dengan cara SADARI terabaikan. Namun, tidak menutup kemungkinan responden yang bekerja akan memiliki pengetahuan yang baik mengenai SADARI. Misalnya, di tempat kerjanya pernah dilakukan pendidikan kesehatan tentang SADARI. Kemudian, misalnya pada responden yang bekerja menjadi PRT (pembantu rumah tangga), mereka mendapat pengetahuan dari tempatnya bekerja.

Pada penelitian ini bukan berarti hanya ibu bekerja saja yang sebagian besar cenderung memiliki pengetahuan kurang. Karena menurut identifikasi yang ada ibu rumah tangga pun juga memiliki pengetahuan kurang mengenai SADARI. Hal ini terjadi karena faktor pendukung lainnya pula. Yaitu rasa ingin tahu responden mengenai berbagai hal yang berhubungan dengan kesehatan yang kurang, sebagian besar masyarakat desa tidak akan mencari tahu mengenai berbagai hal utamanya kesehatan bila mereka tidak ada keluhan yang sangat mengganggu kesehatan badannya.

Selain itu, lingkungan juga sangat mempengaruhi aktivitas individu setempat. apabila masyarakat berada di lingkungan yang memiliki rasa antusias tinggi untuk mencari informasi baru utamanya dalam hal pencegahan kanker payudara dengan SADARI, tidak menutup kemungkinan 
masyarakat tersebut akan memiliki pengetahuan yang baik tentang SADARI. Sebaliknya, apabila di lingkungannya kurang antusias mencari informasi mengenai pencegahan kanker payudara dengan SADARI, maka pengetahuannya juga tidak bisa bertambah tentang SADARI. Dan hal ini sesuai dengan pendapat dari Ann Marine yang dikutip dalam buku Wawan (2011) bahwa lingkungan merupakan seluruh kondisi yang ada di sekitar manusia dan pengaruhnya yang dapat mempengaruhi perkembangan dan perilaku orang atau kelompok.

Pengetahuan WUS setelah diberikan pendidikan kesehatan SADARI diketahui mengalami peningkatan. Terlihat bahwa pada saat sebelum dilakukan pendidikan kesehatan SADARI pengetahuan WUS sebagian besar berkategori kurang, namun pada saat setelah dilakukan pendidikan kesehatan SADARI sebagian besar pengetahuan WUS berkategori baik.

Peningkatan pengetahuan responden ini tidak lepas oleh beberapa faktor pendukung. Baik faktor internal maupun eksternal. Faktor utama dalam penerimaan pengetahuan pada setiap individu adalah dari faktor internal responden. Pada diri responden harus ada rasa ketertarikan terhadap pendidikan kesehatan SADARI karena ketertarikan responden sangat mempengaruhi banyak sedikitnya informasi yang akan diterima oleh responden. Apabila dalam diri responden memiliki rasa tertarik atau memiliki antusiasme yang tinggi untuk mendapatkan informasi mengenai SADARI, maka mereka akan lebih mudah untuk menerima pengetahuan tentang SADARI daripada orang yang kurang memiliki antusiasme dalam mendapatkan pendidikan kesehatan SADARI. Hal ini sesuai dengan proses perilaku "tahu" yang ditulis oleh Wawan (2011) bahwa sebelum mengadopsi perilaku baru dalam diri seseorang terdapat beberapa proses yang berurutan, yaitu awareness (kesadaran) selanjutnya yang kedua interest (merasa tertarik). Tanpa adanya rasa tertarik pada diri responden maka tidak akan bisa pengetahuan tersebut diterima dengan baik oleh responden. Dan tidak akan bisa berlanjut ke proses yang selanjutnya dalam tahapan proses perilaku "tahu" tersebut.
Faktor dari luar juga sangat berpengaruh terhadap banyak sedikitnya informasi yang akan diterima oleh responden. Faktor tersebut meliputi, pemberi materi (penceramah) dan alat peraga yang digunakan dalam mengomunikasikan informasi.

Andita (2014) menyatakan bahwa pemberi materi merupakan salah satu kunci utama keberhasilan dalam memberikan pendidikan kesehatan. Pemateri harus dapat menguasai materi dan audience yang ada. Hal ini sesuai dengan pendapat dari Notoatmodjo (2011) bahwa kunci dari keberhasilan pelaksanaan penceramah tersebut dapat menguasai sasaran ceramah.

Pemateri yang tidak memiliki kemampuan untuk menguasai sasaran, maka informasi yang disampaikan tidak bisa maksimal. Pemateri harus bisa mengomunikasikan materi yang ada dengan tepat pada sasaran yang ada. Misalnya untuk kata yang digunakan menggunakan kata yang disesuaikan dengan tingkat pendidikan responden; pada penelitian ini pendidikan dari responden sebagian besar adalah SD, maka dalam penyampaian informasi perlu diperhatikan, yaitu harus mengunakan kata yang sederhana agar informasi dapat ditangkap dengan baik oleh sasaran. Kemudian bahasa yang digunakan dalam penyampaian informasi. Terutama apabila berada di desa, maka penceramah harus mempertimbangkan mengenai bahasa yang digunakan. Karena pada beberapa daerah di pedesaan mereka (sasaran) tidak memiliki penguasaan Bahasa Indonesia yang baik. Sehingga pemateri harus bisa menguasai bahasa lokal dari tempat sasaran atau bila tidak memungkinkan, harus memiliki rekan yang bertugas untuk menjadi translator sehingga bisa menjembatani dalam pemberian informasi. Selanjutnya penceramah harus memiliki teknik yang dapat menghidupkan suasana sehingga tidak monoton.

Selain itu, adanya perubahan pengetahuan ini juga tidak lupa dengan pemilihan media pendidikan kesehatan. Penggunaan media yang tepat pada pendidikan kesehatan SADARI ini akan mempengaruhi intensitas pengetahuan yang diperoleh responden. 
Media pendidikan kesehatan merupakan suatu sarana yang digunakan untuk menampilkan pesan atau informasi kesehatan yang ingin disampaikan kepada responden sehingga dapat meningkat pengetahuannya yang pada akhirnya diharapkan dapat mengubah perilakunya ke arah positif atau mendukung kesehatan (Mubarak, 2009). Pemilihan media pendidikan yang tepat dapat mempengaruhi peningkatan pengetahuan responden. Pemilihan berbagai media dalam pendidikan kesehatan ini mempertimbangkan pada prinsip bahwa setiap individu memiliki tingkat penangkapan informasi yang berbeda. Misalnya terdapat beberapa orang dengan melihat gambar saja sudah dapat menangkap informasi dengan baik, dan adapula orang yang harus memperagakannya dulu agar dapat menangkap informasi tersebut dengan baik.

Pada penelitian ini, penggabungan dua media yang digunakan. Yang meliputi, slide show dan benda tiruan (phantom). Pada setiap media memiliki tingkat efektivitas yang berbeda. Hal ini sesuai dengan penelitian dalam Supriadi (2014), bahwa media modul lebih efektif daripada media video untuk meningkatkan pengetahuan responden mengenai langkah melakukan SADARI.

Penggabungan beberapa media dalam pendidikan kesehatan SADARI ini, bertujuan untuk memaksimalkan fungsi panca indra yang dimiliki responden agar informasi yang disampaikan lebih banyak yang ditangkap. Karena semakin banyak panca indra yang digunakan maka semakin tinggi intensitas informasi yang bisa ditangkap. Hal tersebut berdasarkan teori yang ada pada piramida Edgar Dale yakni alat peraga disusun berdasarkan prinsip bahwa pengetahuan yang ada pada setiap manusia itu diterima dan ditangkap melalui panca indra. Dan semakin banyak panca indra yang digunakan makan semakin banyak pula pengetahuan yang diperoleh.

Pada Piramida Edgar Dale menunjukkan semakin ke bawah maka semakin banyak pengetahuan yang bisa ditangkap. Pada penelitian ini, untuk media yang digunakan, terutama pada benda tiruan (phantom payudara) termasuk dalam lapisan paling

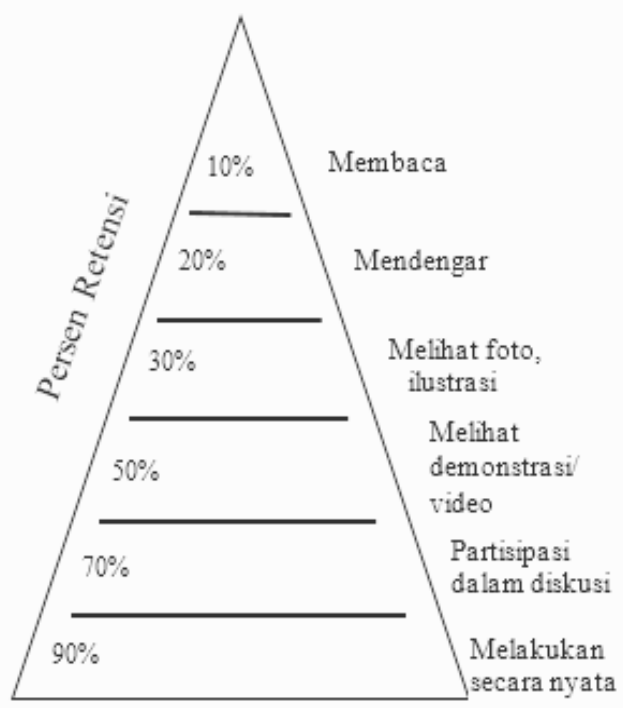

Sumber: Nursalam, 2008

Gambar 1. Piramida Edgar Dale

bawah, yang artinya semakin ke pangkal maka semakin besar panca indra yang digunakan sehingga semakin banyak pula informasi yang bisa ditangkap, dan dapat dipastikan pengetahuan yang diperoleh responden semakin banyak pula. Sehingga intensitas yang didapatkan juga semakin banyak pula. Hal ini dapat dilihat pada Gambar 1. Berdasarkan persen retensi pada Piramida Edgar Dale, apabila responden melihat demonstrasi maka pengetahuan yang diingat sebesar 50\% namun apabila responden melakukan suatu materi pendidikan kesehatan tersebut maka responden akan dapat mengingat $90 \%$ materi tersebut (Nursalam dan Efendi, 2008).

Faktor eksternal yang ada pada pendidikan kesehatan ini juga memiliki kesinambungan dengan faktor internal pada responden. Apabila semakin tinggi rasa ketertarikan responden terhadap rangsangan maka semakin banyak pula informasi yang bisa didapat. Karena tanpa ada rasa ketertarikan dari diri responden maka informasi tidak akan dapat tersampaikan dengan baik juga.

Pengaruh Pendidikan Kesehatan SADARI Terhadap Pengetahuan WUS pada hasil uji statistik menunjukkan bahwa pemberian pendidikan kesehatan SADARI berpengaruh terhadap pengetahuan WUS. Hal ini sejalan dengan penelitian dalam Suastina, dkk 
(2013) bahwa terdapat pengaruh yang signifikan pendidikan kesehatan SADARI terhadap tingkat pengetahuan siswi, selain itu dalam penelitian Hidayati (2012), bahwa pendidikan kesehatan SADARI dengan menggunakan metode ceramah dan demonstrasi berpengaruh terhadap pengetahuan siswi.

Terlihat pada awalnya banyak responden yang berpengetahuan kurang, setelah dilakukan pendidikan kesehatan SADARI maka sudah tidak ada yang berpengetahuan kurang, dan sebagian besar pengetahuannya menjadi baik. Pengetahuan yang baik ini akan mempengaruhi proses dalam pengadopsian perilaku SADARI secara rutin. Karena pengetahuan yang baik merupakan salah satu faktor yang dapat menjadikan perilaku tersebut konsisten untuk dilakukan. Menurut Rogers (1974) dalam Notoatmodjo (2012) bahwa pengadopsian perilaku yang didasari oleh pengetahuan dan kesadaran yang baik, maka perilaku tersebut akan bersifat lama (long lasting), namun apabila tidak didasari dengan pengetahuan maupun kesadaran yang baik maka perilaku tersebut akan bertahan sebentar atau bersifat sementara.

Pendidikan kesehatan SADARI ini merupakan suatu upaya yang dilakukan untuk mempengaruhi responden agar mereka berperilaku sehat. Tujuan dari pendidikan kesehatan SADARI ini untuk mendapatkan masyarakat yang sadar akan kesehatan dan secara aktif melakukan SADARI secara rutin sehingga dapat terdeteksi sedini mungkin apabila terdapat keadaan abnormal pada payudara serta dapat meningkatkan kualitas kehidupannya. Tujuan tersebut sesuai dengan yang ada di dalam UU Kesehatan RI No. 23 Tahun 1992, yaitu:

"Meningkatkan kemampuan masyarakat untuk memelihara dan meningkatkan derajat kesehatan; baik fisik, mental dan sosialnya, sehingga produktif secara ekonomi maupun secara social, pendidikan kesehatan di semua program kesehatan baik pemberantasan penyakit menular, sanitasi lingkungan, gizi masyarakat, pelayanan kesehatan, maupun program kesehatan lainnya."
Apabila masyarakat sadar dan aktif dalam hal melakukan SADARI, maka kanker payudara dapat terdeteksi sedini mungkin. Sehingga dapat dilakukan pengobatan sedini mungkin, dan kematian akibat kanker payudara dapat menurun.

\section{KESIMPULAN}

Terjadi peningkatan pengetahuan pada seluruh responden setelah dilakukan pendidikan kesehatan tentang SADARI. Peningkatan pengetahuan yang sangat signifikan disebabkan pemilihan beberapa media yang digunakan, dengan melakukan penggabungan media slide dan benda tiruan (phantom payudara) maka semakin banyak panca indra yang digunakan dalam menangkap informasi dan semakin banyak panca indra yang dilibatkan maka semakin banyak informasi yang dapat diterima.

\section{SARAN}

Perlu dilakukan pendidikan kesehatan dengan menggunakan penggabungan beberapa media yang berpatokan pada Piramida Edgar Dale dimana semakin banyak panca indra yang digunakan maka semakin banyak juga informasi yang bisa ditangkap oleh audience.

\section{DAFTAR PUSTAKA}

Andita, U. 2014. Pengaruh Pendidikan Kesehatan SADARI Terhadap Pengetahuan WUS di PKK RW 03, Desa Karang Widoro, Kecamatan Dau, Malang. KTI. STIKES Maharani Malang.

Andrews, Gilly. 2009. Buku Ajar Kesehatan Reproduksi Wanita. Jakarta: EGC.

Depkes RI. 2009. Buku Saku Pencegahan Kanker Leher Rahim \& Kanker Payudara. Jakarta: Depkes RI.

Ekanita, P., dan Khosidah A. 2013. Hubungan Antara Pengetahuan dan Sikap WUS Terhadap Perilaku Pemeriksaan Payudara Sendiri (SADARI). Bidan Prada: Jurnal Ilmiah Kebidanan. [e-journal]. 4(1): 167177. Tersedia di <http://ojs.akbidylpp. ac.id/index.php/prada/article/view/75>. [Diakses tanggal 23 Desember 2016]. 
Hidayati,A., Salawat, T., dan Istiana,A. 2012. Pengaruh Pendidikan Kesehatan Melalui Metode Ceramah dan Demonstrasi dalam Meningkatkan Pengetahuan Tentang Kanker Payudara dan Keterampilan Praktik SADARI. [e-journal] 1(1). Tersedia di <http://jurnal.unimus.ac.id/ index.php/jur_bid/article/view/551>. [Diakses tanggal 23 Desember 2016].

IARC. 2013. Latest world cancer statistics Global cancer burden rises to 14.1 million new cases in 2012: Marked increase in breast cancers must be addressed. France: IARC. Tersedia di: $<$ https://www.iarc.fr/ en/media-centre/pr/2013/pdfs/pr223_E. pdf $>$. [Diakses tanggal 23 Desember 2016].

Kemenkes RI. 2014. Profil Kesehatan Indonesia 2013. Jakarta: Kemenkes RI.

Lee, R. 2008. Kanker Payudara. Jakarta: Daras Books.

Manuaba, C.I.A. 2010. Ilmu Kebidanan, Penyakit Kandungan, dan KB untuk Pendidikan Kebidanan. Jakarta: EGC.

Mubarak dan Nurul C. 2009. Ilmu Kesehatan Masyarakat: Teori dan Aplikasi. Jakarta: Salemba Medika.

Mubarak, W.I. 2011. Promosi Kesehatan untuk Kebidanan. Jakarta: Salemba Medika.

Mulyani, N.S. 2013. Kanker Payudara dan PMS pada Kehmilan. Yogyakarta : Nuha Medika.

Nisman, W.A. 2011. Lima Menit Kenali Payudara Anda. Yogyakarta: ANDI.

Notoatmodjo, S.2011. Kesehatan Masyarakat. Jakarta: Rineka Cipta Notoatmodjo, S. 2012. Promosi Kesehatan dan Perilaku Kesehatan. Jakarta: Rineka Cipta.

Nursalam dan Efendi, F. 2008. Pendidikan Dalam Keperawatan. Jakarta: Salemba Medika.

Pamungkas, K.S. 2015. Hubungan Antara Pengetahuan Ibu Tentang Kanker Payudara dengan Perilaku SADARI Pada Kader Posyandu Kecamatan Delanggu. Skripsi. Universitas Muhammadiyah Surakarta. Tersedia di $<$ http://eprints.ums.
ac.id/37946/13/Naskah\%20Publikasi. pdf $>$ [27 Desember 2016].

Purwanto, D.J. 2010. Deteksi Dini Kanker Payudara. [Online] tersedia di: <http:// www.omni-hospitals.com/omni alamsutera/blog_detail.php?id_post=5>. [Diakses tanggal 22 Januari 2013].

Romauli, Suryati. 2009. Kesehatan Reproduksi buat Mahasiswi Kebidanan. Yogyakarta : Nuha Medika Nisman 2011.

Suastina, I.D.A.R., Ticoalu, A.H.R., dan Onibala, F. 2013. Pengaruh Pendidikan Kesehatan Terhadap Tingkat Pengetahuan Siswi Tentang SADARI Sebagai Deteksi Dini Kanker Payudara di SMA Negeri 1 Manado. Journal Keperawatan. [e-journal] 1(1): 1-6. Tersedia di <http:// ejournal.unsrat.ac.id/index.php/jkp/ article/view/2188>. [Diakses tanggal 27 Desember 2016].

Supriadi, Purwanti, S., dan Sumiati. 2014. Perbedaan Pengaruh Pendidikan Kesehatan dengan Menggunakan Media Video dan Media Modul terhadap Perubahan Pengetahuan dan Perilaku tentang Praktik Sadari Pada Siswi Kelas XI SMA. Jurnal Husada Mahakam [e-journal] 1(8): 319-442. Tersedia di $<$ https://husadamahakam.files. wordpress.com/2015/12/6-jurnal-susi. pdf $>$. [Diakses tanggal 23 Desember 2016]. UU RI No. 23 Tahun 1992 Tentang Kesehatan. Jakarta: Presiden RI.

Wawan, A. dan Dewi, M., 2011. Teori dan Pengukuran Pengetahuan, Sikap dan Perilaku Manusia. Yogyakarta: Nuha Medika.

Widiawaty, N., 2011. Hubungan Tingkat Pendidikan Formal dan Tingkat Pengetahuan Wanita Tentang Kanker Payudara dengan Kejadian Kanker Payudara di Borokulon Banyuurip Purworejo. Jurnal Komunikasi Kesehatan [e-journal] 2(02):1-5. Tersedia di <file:///C:/Users/Win 8.1/ Downloads/57-114-1-SM.pdf>. [Diakses tanggal 23 Desember 2016]. 